Seyedtaghi Mirmohammadi ${ }^{1}$

Yosef Moghaddasi ${ }^{1}$

Jamshid Yazdani ${ }^{2}$

Razyeh Yousefinejad ${ }^{3}$

Yahya Esfandyari ${ }^{4}$

Mohsen Gorgani ${ }^{3}$

Manijeh Habibpour ${ }^{5}$

\title{
CORRELATION BETWEEN AIRBORNE MANGANESE CONCENTRATION AT THE WORKSTATIONS IN THE IRON FOUNDRY AND MANGANESE CONCENTRATION IN WORKERS' BLOOD
}

\author{
Mazandaran University of Medical Sciences, Sari, Iran \\ ${ }^{1}$ Molecular and Cellular Biology Research Center \\ ${ }^{2}$ Faculty of Health Sciences, Department of Biostatistics \\ ${ }^{3}$ Faculty of Health Sciences, Department of Occupational Health \\ ${ }^{4}$ Faculty of Health Sciences, Department of Environmental Health \\ ${ }^{5}$ Faculty of Pharmacy
}

\begin{abstract}
Background: Manganese (Mn) used as raw material for melting process in the ferrous foundry is considered as hazardous neurotoxic substance because it accumulates in the central nervous system and may cause neurological disorders. The furnace-men and melting department workers are potentially exposed to manganese particles or fume in the workplace. The objective of the research has been to investigate the sources and levels of manganese exposure in the foundry by correlation of blood-manganese (B-Mn) and air-manganese (air-Mn) measurement. Material and Methods: Air-Mn and Mn of blood serum were measured involving workers who worked in a big-sized foundry during 1 year. The standard method of the Occupational Safety and Health Administration (OSHA) ID-121 was used for air and blood assessment and atomic absorption spectroscopy (AAS) was carried out for air and blood sample analysis. Results: The air sampling results have revealed that there is a high exposure to manganese $\left(4.5 \mathrm{mg} / \mathrm{m}^{3}\right)$ in the workplace as compared to the National Institute for Occupational Safety and Health's (NIOSH) time weighted average (the reference time-weighted average (TWA) $=1 \mathrm{mg} / \mathrm{m}^{3}$ ). The average blood serum Mn concentration was $2.745 \mu \mathrm{g} / \mathrm{l}$ for subjects working for shorter than 3 months and $274.85 \mu \mathrm{g} / \mathrm{l}$ for subjects working 3-12 months. Conclusions: Against the research hypothesis there was no correlation between the air-Mn concentration and the B-Mn (serum) level of manganese in the serum of the exposed subjects. It may be due to short time of air sampling of manganese airborne particles, and a real-time monitoring of airborne manganese particles is suggested for any future study. Med Pr 2017;68(4):449-458
\end{abstract}

Key words: atomic absorption spectroscopy, foundry, blood assessment, manganese airborne particle, air and blood assessment, workers

Corresponding author: Seyedtaghi Mirmohammadi, Mazandaran University of Medical Sciences,

Molecular and Cellular Biology Research Center, Farahabad Ave, 48168-18975, Sari, Iran, e-mail: seyedtaghim@gmail.com Received: October 5, 2015, accepted: April 5, 2017

\section{INTRODUCTION}

The melting process involves foundry; crushing and grinding of molding materials generates a variety of particulate matters (PM) and dust in the workplaces, and the process is characteristic of very high-temperature. The polishing and finishing process uses sandblasting and drilling that are both environmentally pollutant for individuals and factories.
Ferrous foundry workers are exposed to various manganese (Mn) airborne particles and fumes in the workplaces from both naturally occurring processes and processing activities; because of their small size, fine particles tend to remain and suspending in the air for long periods of time (weeks or months) [1]. Occupational risk assessment is important in foundries and has mainly been based upon airborne manganese measurements. A time weighted average (TWA) expo-

Funding: the study was funded and approved by Mazandaran University of Medical Sciences Boards through the project "Assessment of manganese exposure and serum level of manganese among foundry workers," No. 392. Project manager: Seyedtaghi Mirmohammadi, Ph.D., Assist. Prof. 
sure limit to manganese dust of about $1 \mathrm{mg} / \mathrm{m}^{3}$ has been reported to cause preclinical adverse effects of $\mathrm{Mn}$ in the central nervous systems in the case of exposed workers for shorter than 20 years of experience [2]. Studies have revealed a basic sub-clinical intoxication which has been observed in manganese exposed workers with moderate $(1 \pm 4 \mu \mathrm{g} / \mathrm{l})$ increases in blood manganese (B-Mn) [3,4].

The foundry furnace men are potentially exposed to manganese pollution during melting, weighting, transportation of recycled manganese-alloyed iron scrap from storehouses to a furnace as well as manganese fumes exposure from the furnaces, especially during smelting in the foundry workplace. The non-furnace workers may be potentially exposed to manganese during the handling of manganese-alloyed iron and preparing of the production and maintenance. The indoor air study has assessed factory pollutant problems that may affect human health, including statistical models such as a regression model or multiple model for pollution estimation with the emphasis on particle matter in the workplaces.

Researchers have pointed out that the consequences of exposure to manganese in the workplace and uptake of this element in the body will bring about the central nervous system disorder, which would be called manganism, as the complications; there are many similarities with Parkinson's disease [5-12]. One of the most important scientific methods, particularly to determine the exposure to pollutants, is biological monitoring of workplaces [13-15]. Bio-monitoring methods are usually carried out in a limited period of time and in certain circumstances of the level of pollutants concentration in blood plasma, search, urine, feces, nails, etc., using laboratory analysis equipment [13-15]. According to studies, pollution criteria for exposed people were $\geq 4 \mu \mathrm{g} / \mathrm{ml}$ concentrations of $\mathrm{Mn}$ in subjects' blood; for the pollutants poisoning workers, $1-4 \mu \mathrm{g} / \mathrm{l}$ has been set as an indicator of normal range $[7,16,17]$.

Studies have shown the biological half-life of manganese in the human body against 20-40 days, and after this period it gets reduced and returns to the amount of manganese or natural serum level for people. The daily ongoing work in the midst of manganese makes up the additional amounts in the body, that will be excreted through the urine [7,16-18]. A study was conducted by Laohaudomchok et al. [10] on bio-monitoring of manganese for workers exposed to manganese particles; in this research, workers who had had work experience from 1 month to 1 year, showed significant manganese concentrations in the months 7-9 and months 9-12 in high and reposition of the nails in months 7-12 but it has not been seen in months $1-6$ of the first work experience [10].

In another study done by Chang et al. [13] on workers exposed to manganese fume, they compared the results of the evaluation by magnetic resonance imaging (MRI) scans and neurological testing area of the brain and the results of serum manganese and workers and the control group $(\mathrm{N}=43)$ [13]. The results have not shown the differences between the MRI scans and the control group workers but a significant difference was seen in the case of testing the blood of these individuals for $\mathrm{Mn}$ as compared to the control group [13]. The objectives of this study have been to evaluate Mn occupational exposure by measuring Mn concentration and finding correlation of $\mathrm{Mn}$ pollution and indoor psychometric parameters, such as dry bulb temperature $(\mathrm{Td})$, relative humidity (RH), air velocity (or wind speed) and altitude in the foundry factory.

In order to assess the level of manganese in blood of exposed workers for longer than 1 year of work experience, it was carried out for exposed workers for shorter than 3 months of work experience, moreover, comparison of 2 separate blood plasma examinations result in the emphasis on manganese level.

\section{Study design}

The study was conducted in a big ferrous foundry factory in Iran. Based on the study objectives, the indoor manganese particles $(\mathrm{Mn})$ concentration was measured during a working shift in the foundry factory. One hundred workers exposed to manganese particles were subject to this study location. A simple questionnaire was used for recording the individual information for participant workers. Questions were asked about age, weight, height, seniority, previous experience and smoking.

\section{MATERIAL AND METHODS}

Fifty workstations (in furnace, melting, molding, blasting, drilling, finishing and transporting task) were chosen for the air sampling during a working shift in this study. Sampling and data collection and results documentation were done in accordance with the National Institute for Occupational Safety and Health's (NIOSH) guidelines and standards.

\section{Airborne manganese (air-Mn) sampling and analytical method}

The latest Mn particle sampling methods (the Occupational Safety and Health Administration's (OSHA) ID-121 
method and NIOSH method No. 7301) were chosen and used for this study. The Mn particle sampler was Dewell Higgins-type respirable cyclone (part No. 225-69) and $25 \mathrm{~mm}$ MCE $0.8 \mu \mathrm{m}$ pore size ester cellulosic filters (part No. 225-19, pk/50) (SKC, USA).

Indoor samples were taken in the workplaces in the working time for TWA via personal sampling method. It is supported by a stainless steel screen that is supplied with the personal environmental monitor. In the laboratory room meteorological parameters were set at $22^{\circ} \mathrm{C}$ and $40 \%$ as a permissible temperature and relative humidity, respectively. The personal sampling pump Leland Legacy (SKC, USA) was calibrated by means of a soap film flow meter in the laboratory at $2 \mathrm{l} / \mathrm{min}( \pm 5 \%)$, and distributed to the workers for personal sampling. After sampling, all the ester cellulose filters had been stored in a laboratory refrigerator at $4^{\circ} \mathrm{C}$ until they were analyzed (storage duration is 90 days). Samples were analyzed at the same time in the Laboratory of Organic Pharma-chemistry, the Faculty of Pharmacology, the Mazandaran University of Medical Sciences, Sari, Iran. Manganese concentration was measured by means of the graphite furnace-atomic absorption spectrometry (GF-AAS).

The cellulose ester filters were suspended in a solvent (including: $2 \mathrm{ml}$ of 35\% hydrochloric acid and 65\% nitric acid $(40: 60 \mathrm{v} / \mathrm{v}))$ and the temperature increased up to $90^{\circ} \mathrm{C}$ for $60 \mathrm{~min}$ and changed the samples almost to dryness. The samples were injected into a 4100-ZAAS spectrometer (Perkin Elmer, Germany) (wavelength = $279.5 \mathrm{~nm}$, lamp current $=20 \mathrm{~mA}$, gap $=0.2 \mathrm{~nm}$, matrix modifier $=10 \mathrm{l}$ ) after another $24 \mathrm{~h}$ at room temperature. Interferences from the matrix were minimized by the use of the Zeeman-effect background compensation and automated standard addition calibration. The detection limit for manganese in air was $2 \mathrm{ng} / \mathrm{m}^{3}$ under the conditions of the above-described sampling procedure. A dry thermometer and Asman hygrometer was used for measuring indoor dry bulb temperature and relative humidity in the study workplace.

\section{Blood manganese (B-Mn) sampling and analytical method}

A simple checklist was used for recording the workers' examination results, clinical symptoms and disease history of subjects. According to the biological half-life of manganese that remains in the human body for 20 40 days, $4 \mathrm{ml}$ of sample blood was collected by disposable syringes and the samples were poured into a flask containing ethylenediaminetetraacetic acid (EDTA) [8].
For sample preparation and analysis methods of occupational medicine, the reference book as well as the method in accordance with OSHA standard ID-121 and the method was used, thanks to which Bader by using atomic absorption spectroscopy (AAS) method of manganese metal concentrations in blood samples had determined the amount of workers [14]. After blood sampling, the blood's serum for samples was separated by Sigma centrifuge machine model 3-10 (SciQuip, United Kingdom) and 3000 rounds for 5 min into lab and then frozen. According to the recommended procedure, first $2 \mathrm{ml}$ of blood inside the syringe discarded the possibility of the existence of potential $\mathrm{Mn}$ in the syringes, then all the samples were frozen in $-27^{\circ} \mathrm{C}$.

The amount of $100 \mu \mathrm{l}$ of blood inside the vial containing $900 \mu \mathrm{l}$ of Triton X-100 (Sigma-Aldrich, Germany) was added and $20 \mu \mathrm{l}$ of it was injected to an atomic absorption machine. This method determines the time limit of $0.5 \mu \mathrm{g} / \mathrm{l}$. A furnace atomic absorption (Perkin Elmer, Germany) was used for determining the amount of manganese in blood of workers. The atomic absorption device was set to $279.5 \mathrm{~nm}$ wavelength and the device was equipped with lamps $10 \mu \mathrm{g} / 10.2 \mathrm{~nm}$, gap matrix modifier [14].

The bioethic consent for this study in terms of code No. 392-1392 was registered by the Bioethics Committee of Mazandaran University of Medical Sciences, Iran.

\section{Sample size and statistical analysis}

For air-Mn and B-Mn, the sample size required to be produced as an estimate of the total number of samples and subjects (or of potentially exposed workers) within specified limits, with $95 \%$ confidence interval, using the following formula:

$$
\mathrm{n}_{1}=\mathrm{n}_{2}=\frac{\left[\mathrm{Z}_{1-\alpha / 2}+\mathrm{Z}_{1-\beta}\right]\left[\sigma_{1}^{2}+\sigma_{2}^{2}\right]}{\left(\mu_{1}-\mu_{2}\right)^{2}}
$$

where:

$\mathrm{n}_{1}$ - air samples (air-Mn),

$\mathrm{n}_{2}$ - blood samples (B-Mn),

$Z_{1-\alpha / 2}$ - error I $(\alpha=0.05)$,

$Z_{1-\beta}$ - error II $(\beta=0.29)$,

$\sigma_{1}^{2}-$ variance in group I (study) (0.2),

$\sigma_{2}^{2}-$ variance in group II (control) (0.17),

$\mu_{1}-$ mean in group I (study) (0.38),

$\mu_{2}$ - mean in group II (control) (0.54).

Using the formula above for statistical estimation of the number of exposed workers, 60 subjects were 
chosen randomly to prepare blood serum samples in 2 separate groups of 30 people but because of some subjects' refusal to participate in the study, they were separated into 2 groups with 35 persons [19].

Multiple linear regression attempts to correlate the relationship between 2 or more variables and a response variable by fitting a linear equation to observed data and other researchers used regression techniques to correlate pollutant indicators as a function of psychometric parameters and other factors, relevant to factory, such as dry bulb temperature, relative humidity, dimension of factory and altitude of factory. The correlation between $\mathrm{Mn}$ airborne particles and psychometric variables may be understood better by using multiple regression correlations. For statistical analyses in this study, the result was analyzed by means of the SPSS version 20 (IBM, USA).

\section{RESULTS}

Fifty air samples were collected from the workplace by means of the stationary sampling method. The study workstations also included maintenance employees working in the workplaces. Sampling zones were selected at random from within the corresponding frequency categories because there were many worksta- tions where workers worked in the factory. The study subjects worked in a big-sized foundry factory with a poor insufficiently ventilated smelting and inhale, absorb, and retain significant amounts of manganese in the form of particle or fume in their pulmonary system and then pass it to blood. The manganese biomonitoring was carried out among exposed workers who worked in the foundry factory. They were categorized as W1, W2, W3, W4 and W5 groups related to their working stations. The subjects were classified into 2 groups - subjects who had been working for shorter than 3 months as group I and workers with 3-12 months working experience as group II. Moreover, there was a separate group as the control cluster. The Table 1 shows age, weight, height and seniority of study and the control group.

Based on the latest study in the same workplaces, this research was conducted, so the highest mean value of manganese $(\mathrm{Mn})$ concentration was $4.5 \mathrm{mg} / \mathrm{m}^{3}$ from indoor air samples (Table 2).

The average Mn concentration of the subjects' blood serum (B-Mn) was $2.745 \mu \mathrm{g} / \mathrm{l}$ and $274.85 \mu \mathrm{g} / \mathrm{l}$ for shorter than 3 months $(\mathrm{N}=35)$ and 3-12 months working experience $(\mathrm{N}=35)$, respectively (there were 5 different workstations and 7 samples were selected per each station). The maximum concentration of B-Mn mea-

Table 1. Characteristics of the control group and manganese (Mn) exposed workers of the iron foundry in Iran, 2015

\begin{tabular}{|c|c|c|}
\hline Characteristics & $\begin{array}{l}\text { Study group } \\
\quad(\mathrm{N}=35)\end{array}$ & $\begin{array}{l}\text { Control group } \\
\qquad(\mathrm{N}=35)\end{array}$ \\
\hline Age [years] $(\mathrm{M} \pm \mathrm{SD})$ & $38 \pm 9$ & $34 \pm 6$ \\
\hline Height $[\mathrm{cm}](\mathrm{M} \pm \mathrm{SD})$ & $172 \pm 9$ & $173 \pm 8$ \\
\hline Seniority [months] (range) & $1-12$ & $1-12$ \\
\hline
\end{tabular}

$\mathrm{M}$ - mean, SD - standard deviation.

Table 2. Airborne manganese (air-Mn) concentration at the workstations in the iron foundry in Iran, $2015^{*}$

\begin{tabular}{|c|c|c|c|}
\hline \multirow{2}{*}{$\begin{array}{l}\text { Workstation } \\
\quad \text { (task) }\end{array}$} & \multicolumn{3}{|c|}{$\begin{array}{l}\text { Air-Mn concentration } \\
{\left[\mathrm{mg} / \mathrm{m}^{3}\right]}\end{array}$} \\
\hline & M & $\min$. & $\max$ \\
\hline Furnace $(\mathrm{N}=7)$ & 3.040 & 2.100 & 4.500 \\
\hline Melting $(\mathrm{N}=7)$ & 1.950 & 1.614 & 1.920 \\
\hline Pouring $(\mathrm{N}=7)$ & 1.071 & 1.000 & 1.200 \\
\hline Surface cleaning $(\mathrm{N}=7)$ & 0.825 & 0.700 & 1.000 \\
\hline Finishing $(\mathrm{N}=7)$ & 0.478 & 0.500 & 0.610 \\
\hline
\end{tabular}

* National Institute for Occupational Safety and Health (NIOSH) time weighted average for Mn concentration in air is $1 \mathrm{mg} / \mathrm{m}^{3}$ [9].

$\mathrm{N}$ - number of samples, $\mathrm{M}-$ mean, min. - minimal value, $\max -$ maximal value. 
sured from workers' serum in the foundry was $23.5 \mu \mathrm{g} / \mathrm{l}$ and $590 \mu \mathrm{g} / \mathrm{l}$ for shorter than 3 months and 3-12 months working experience, respectively.

The Table 3 shows the descriptive statistical analysis of the study results. The results of blood serum (serum) analysis indicated high exposure with respect to $\mathrm{Mn}$ because of the lowest concentration of $\mathrm{Mn}$ in their serum that was $0.5 \mu \mathrm{g} / \mathrm{l}$ and $100 \mu \mathrm{g} / \mathrm{l}$ for shorter than 3 months and 3-12 months working experience, respectively. This value was higher than the guideline value $(1-4 \mu \mathrm{g} / \mathrm{l})$. Quite a few studies stated that the accumulation of Mn occurred based on the exposure of the human brain via blood stream (the half-life of $\mathrm{Mn}$ in the human blood is 10-42 days). This advocates that urine sample collection for biological monitoring should be done at the end of the exposure day [20-22]. Since the Mn half-life in the blood serum is between 20-40 days, the results reflect the levels after occupational exposure before the end of half-life. The values of $\mathrm{B}-\mathrm{Mn}$ in the serum samples are shown in the Table 2 and Table 3.

It reveals that a group of workers involved in pouring, surface cleaning and finishing workstations had the lowest Mn exposure $\left(0.825 \mathrm{mg} / \mathrm{m}^{3}\right.$ and $0.478 \mathrm{mg} / \mathrm{m}^{3}$, respectively) and also the highest $\mathrm{Mn}$ concentration was seen in furnace and melting workstations at $4.5 \mathrm{mg} / \mathrm{m}^{3}$ and $1.92 \mathrm{mg} / \mathrm{m}^{3}$, respectively. On the other hand, 2 groups of workers involved in the furnace workstation and melting station revealed highest exposure to $\mathrm{Mn}$ pollution and anticipated the highest Mn concentration in their blood's serum at exposed subjects who worked in the furnace and melting workstations in the foundry factory (Tables 2 and 3). The results of this study revealed accumulation of $\mathrm{Mn}$ pollution as a toxic element that was found among exposed workers who had been working between 3-12 months in the foundry factory as furnace men or melting operators. In this study only the group of workers with 3-12 months experience demonstrated a straight correlation between indoor air-Mn pollution and $\mathrm{Mn}$ in the blood serum samples taken from workers, as also shown in the Table 3 and Table 4.

It may be seen that Mn concentration in the air is directly related to $\mathrm{Mn}$ concentration in the blood of workers with an ANOVA correlation coefficient at $\mathrm{R}^{2}=0.057$ and the significance level below 0.001 . This means that as the Mn concentration in the air of the factories increases, the Mn level in the blood serum of subjects also increases. The regression model for air-Mn and B-Mn (serum) for the group with 3-12 months working experience indicates that the $t$ value is 0.238 .

In order to assess the Mn concentration in the workstation, the air samples were collected from the sub-

Table 3. Blood manganese (B-Mn) concentration in the control group and Mn exposed workers of the iron foundry in Iran, 2015*

\begin{tabular}{|c|c|c|c|}
\hline \multirow{2}{*}{ Respondents } & \multicolumn{3}{|c|}{$\begin{array}{c}\text { B-Mn concentration } \\
{[\mu \mathrm{g} / 1]}\end{array}$} \\
\hline & M & $\min$. & $\max$ \\
\hline \multicolumn{4}{|l|}{ Study group $(\mathrm{N}=35)$} \\
\hline working $<3$ months & 2.745 & 0.5 & 23.5 \\
\hline \multicolumn{4}{|l|}{ Control group $(\mathrm{N}=35)$} \\
\hline working $<3$ months & 0.314 & 0.0 & 1.0 \\
\hline working 3-12 months & 0.398 & 0.0 & 2.0 \\
\hline
\end{tabular}

* Standard level for Mn concentration in blood $=1-4 \mu \mathrm{g} / \mathrm{l}[9]$.

Abbreviations as in Table 2.

Table 4. Estimated marginal mean blood manganese (B-Mn) concentration in Mn exposed workers of the iron foundry in Iran, 2015

\begin{tabular}{lccc}
\hline \multicolumn{1}{c}{ Grouped deviation contrast } & Contrast estimate & $\mathrm{SE}$ & $\mathrm{df}$ \\
\hline $\begin{array}{l}\text { Concentration of Mn in blood in study group } \\
\text { vs. mean concentration of Mn in blood }\end{array}$ & 12.23 & 1.015 & 1 \\
$\begin{array}{l}\text { Concentration of Mn in blood in control group } \\
\text { vs. mean concentration of Mn in blood }\end{array}$ & -12.23 & 1.015 & 1 \\
\hline
\end{tabular}


jects breathing zone in workstations (Table 5). A positive and linear relationship between workplace air-Mn pollutant and serum-Mn concentrations was found for subjects who had 3-12 months working experience. No background $\mathrm{Mn}$ was detected in the workers and the relationship validated $\mathrm{Mn}$ as an initial indicator of a preceding exposure of workers to $\mathrm{Mn}$ with $\mathrm{R}=0.543$ (Table 6).

The ANOVA and F-test for the regression analysis is shown in the Table 6 and Table 7, thus, the regression model predicts the exposure to airborne Mn pollutant significantly as compared to $\mathrm{Mn}$ concentration in the exposed workers' blood serum.

\section{DISCUSSION}

The average of Mn concentration in the studied workplaces was $1.473 \mathrm{mg} / \mathrm{m}^{3}$ and when compared to the value recommended by NIOSH, it appeared to be extremely high (Table 2). The result of this study was slightly high as compared to that of the other factories in different countries [15]. While duration of work in the workplaces is an important factor to determine personal exposure to particles, it is supposed that health condition of subjects accounts for different exposure conditions as compared to the general population and the exposure results are similar to other research finding in another country [16]. Based on high personal exposure to $\mathrm{Mn}$ in this study, the obtained result is not comparable with another study that has been conducted by researchers [17]. The correlation between the average of indoor air variables and personal exposures to indoor dust such as $\mathrm{Mn}$ is not strong and a straight relationship has been seen between Mn pollution and condition of indoor psychometric parameters, such as relative humidity and dry bulb temperature.

This finding is comparable with other results [18]. The positive relationship between temperature and $\mathrm{Mn}$ concentration may be expected as it is reported in the literature with emphasis on dust exposure [23], due to

Table 5. Multiple regression analysis for airborne manganese (air-Mn) concentration at the workstations and blood manganese (B-Mn) concentration in the workers of the iron foundry in Iran, 2015

\begin{tabular}{lcccc}
\hline & $\begin{array}{c}\text { Model } 1^{*} \\
(B-M n \text { vs. air-Mn) }\end{array}$ & Sum of squares & df & p \\
\hline Regression & 566.237 & 1 & 2.531 & $0.119^{\mathrm{a}}$ \\
Residual & $9394.673^{\mathrm{b}}$ & 42 & \\
Total & 9960.909 & 43 & \\
\hline
\end{tabular}

* Regression model for B-Mn vs. air-Mn, F test.

$\mathrm{df}$ - degrees of freedom, $\mathrm{F}$ - test of statistical significance.

a Predictors (constant): air-Mn concentration.

${ }^{\mathrm{b}}$ Dependent variable: B-Mn concentration.

Table 6. Regression model test by ANOVA for correlation between blood manganese (B-Mn) concentration in Mn exposed workers working 3-12 months and airborne manganese (air-Mn) concentration at the workstations in the iron foundry in Iran, $2015^{\star}$

\begin{tabular}{|c|c|c|c|c|c|}
\hline Variable & $\mathrm{R}^{2}$ & $\mathrm{R}_{\text {adj }}^{2}$ & SE estimate & $\eta$ & $\eta^{2}$ \\
\hline B-Mn concentration vs. air-Mn concentration & 0.295 & & & 0.879 & 0.773 \\
\hline Model $1^{\star *}$ & 0.057 & 0.879 & 0.773 & & \\
\hline
\end{tabular}

* Predictor (constant): air-Mn concentration.

${ }^{* *}$ Regression model for B-Mn vs. air-Mn.

$\mathrm{R}$ - reliability, $\mathrm{R}_{\text {adj }}^{2}$ - adjusted coefficient of explained variance, SE estimate - standard error, $\eta$ - effect size.

Table 7. Multiple regression analysis for airborne manganese (air-Mn) concentration at the workstations and blood manganese (B-Mn) concentration in the workers of the iron foundry in Iran, $2015^{\star}$

\begin{tabular}{lcccc}
\hline & Parameter & $\beta$ & $\mathrm{B}$ & $\mathrm{p}$ \\
\hline Constant & 0.000 & 15.667 & 0.0001 \\
Air-Mn & 1.591 & 5.928 & 0.238 \\
\hline
\end{tabular}

* Dependent variable: $\mathrm{B}-\mathrm{Mn}$ concentration.

$\beta$ - standardized coefficient, B - non-standardized coefficient, $t$ test. 
an exponential increase in fine particulate matters emission rate in the course of curing the melting process.

It was observed that in the range of typical room temperatures $\left(20-30^{\circ} \mathrm{C}\right)$ there was only small effect on emission. However, at temperatures greater than $30^{\circ} \mathrm{C}$, a clear increase in emission was noticed. The workplace dry bulb temperatures within this study ranged $22-27^{\circ} \mathrm{C}$. The linear relationship between temperature and $\mathrm{Mn}$ concentration was acceptable since the indoor temperatures were not greater than $30^{\circ} \mathrm{C}$, due to an exponential increase of $\mathrm{Mn}$ particulate emission could occur [24].

The obtained regression predictive model in this study is corresponding with other findings that has been achieved by other researchers [25]. They have illustrated that determined pollution is compared to the predictions of the thermodynamic Gibbs Free Energy Minimization (GFEMN) and aerosol inorganics model (AIM), in order to estimate the contribution of particulate matters to water absorption [26]. A direct comparison with the obtained particulate matters model is possible for the GFEMN and AIM models that have served the purpose of calculating the amount of aerosol bound water based on the measured relative humidity and the particulate matter $\left(\mathrm{PM}_{2.5}\right)$ aerosol concentrations [27]. Researchers previously used the regression techniques to correlate pollutants' indicators as a function of psychometric parameters and other factors relevant to the factory, such as dry bulb temperature, relative humidity, dimension of factory and altitude of factory [28]. The results of this study are comparable with the study that was conducted by Zhou et al., but they evaluated a variety of biological samples by means of the atomic absorption technique and reported the high amounts of manganese in urine, saliva, hair, blood and plasma (32.17 g/l, $37.39 \mathrm{~g} / 1,2.5 \mathrm{~g} / 1,129.61 \mathrm{~g} / \mathrm{l}$ and $4.49 \mathrm{~g} / \mathrm{l}$, respectively) [11].

The obtained results have shown the high pollution of airborne manganese particles in the studied workplace and it is slightly close to the finding that was reported by Ellingsen et al., revealing the respirable manganese concentration that was $254 \mu \mathrm{g} / \mathrm{m}^{3}$ and it assessed within 3 days for 100 of exposed workers [29]. This result is slightly lower than the result that was obtained in the same research [21]; the variety of blood serum samples was the same $(\mathrm{N}=100)$ as in that study: the samples analysis by means of the atomic absorption method showed that the level of manganese in blood's serum was equal to the air pollutants' concentrations. Comparing to this study, the finding of another study is not approximate and is moderately high [21]. They illustrated that the Mn particles concentration was $5.08 \mathrm{mg} / \mathrm{m}^{3}$ and it was reported that $69 \%$ of all workers had been faced with the Mn pollution [21].

Based on the results that this value is higher than the permitted threshold, nervous system disorders and the incidence of various central nervous system disorder signs are expected to occur in the case of the exposed workers. Accordingly, a straight correlation between air concentration of $\mathrm{Mn}$ and blood serum level of Mn was seen in this study, and as compared to Bast-Pettersen et al. study, the exposure to manganese particles in the air with concentration of $301 \mu \mathrm{g} / \mathrm{m}^{3}$ proved the direct correlation with manganese concentration in the blood, and urine of exposed workers (181 $\mathrm{mmol} / \mathrm{l}$ and $0.9 \mathrm{nmol} / \mathrm{mmol}$ creatinine, respectively) [28]. The research was done by Cowan et al. to report that the concentration of manganese in the inhaled air of exposed workers had a significant relationship with the ratio of $\mathrm{Mn} / \mathrm{Fe}$ of erythrocytes $(r=0.77$, $\mathrm{p}<0.01)$ and the workers' blood plasma $(\mathrm{r}=0.7$, $\mathrm{p}<0.01)$ [30]. Other researchers' finding was higher than this research finding for $\mathrm{Mn}$ in air and blood level but a straight relationship was seen between air-Mn and B-Mn (serum).

In the other study, the average of manganese concentrations was $215-978 \mu \mathrm{g} / \mathrm{m}^{3}$ for workers in the workplace and the same amount of manganese levels in blood and urine of exposed workers is high [23]. Studies have shown the biological half-life of manganese in the human body against 20-40 days, and after this period the amount of manganese in the workplace decreased or normal serum level would return. Given the daily ongoing additional amounts in the period, that had been inserted into the body through the urine, were excreted $[18,24,30]$. According to the textbook by Zenz [15], the main way to enter Mn pollutants into the human body is through inhaled manganese, and the lungs and human brain are the target and any metabolism in other organs of the body and organs were not the one.

During the study, 2 of the participants found as subjects had some exhibited specific neurological symptoms in this study. The entire subjects showed the highest B-Mn levels, i.e., around $210 \pm 30 \mu \mathrm{g} / \mathrm{l}$, including 2 subjects (had neurological disease symptoms). They $(\mathrm{N}=2)$ had a severe neurological disease, musculoskeletal disorder and physical problem especially for walking, sitting, speaking, etc., and they were aged 33 and 40 years old. Based on the obtained in- 
terview information data, the symptoms appeared after 5 years of occupational exposure to manganese fume and their B-Mn levels fell too high levels, which indicated a degree of relative neurological symptoms at an early stage.

Unfortunately one of them died after 5 years of selfexpulsion. Other studies revealed that in highly advanced stages, the neurological symptoms of subjects were irreversible [4-28]. A straight correlation between neurological symptoms and B-Mn levels was reported in some studies in the literature [7,23]. According to the biological half-life in brain tissue, it is probably around 1 year; it is generally proposed that manganese is eliminated from the human central nervous system for a long period and at very slow rate [31]. Moreover, this knowledge is helpful for neurologists for diagnosis and treatment of patients who have neurological disorder symptoms with working experience in foundry workplaces. Manganese particles according to size and duration of chronic toxicity in the target organ of the job with these contaminants may account for reproductive organs, lungs, and brain cells are the basis of the central nervous system. The average increase in B-Mn (serum) was seen in the concentration of the pollution control rate up to $24.9, \mathrm{p}<0.001$.

Regarding the impact of various workstations on the amount of manganese concentration in the blood serum of workers, using the method of statistical analysis of the results of the review, the generalized estimating equation (GEE) was suitable for the current study [19]. It also stated that those findings had shown significant differences for exposed workers with more than 3 months of work experience (on average $24.9 \mu \mathrm{g} / \mathrm{l}$ ) as compared to the control group with confidence intervals of $95 \%$ or $\alpha=0.05$.

\section{CONCLUSIONS}

The obtained predictive regression model of $\mathrm{Mn}$ for the foundry factory based on psychometric parameters in this study shows that the relative humidity and dry bulb temperature are the main factors influencing Mn concentration in the workplaces. The indoor air quality evaluation in this study has revealed that the increase in indoor air exposure to manganese particles or fumes in the workplaces has caused increase in manganese level in the exposed workers' blood. This is due to the chronic exposure of subjects and related to working experience in the foundry workplace (in this study more than 3 months). Against the research hypothesis, there was no correlation between the air-Mn concentration and the B-Mn (serum) level of manganese in the serum of the exposed subjects. It may be due to short time air sampling of manganese airborne particles, and a real-time monitoring of airborne manganese particles suggested for any future study. Using the current findings about the impact of particulate manganese inhalation by exposed workers will provide the best health program in the related industries and the authorities of the country's health issue that leads to protect workers in small industries.

\section{ACKNOWLEDGMENTS}

The authors gratefully acknowledge the technical support of the Faculty of Health in the Medical University of Mazandaran, Iran, and also especially thanks for Samaneh Dehghan, M.Sc., for technical facilities.

\section{REFERENCES}

1. Meléndez A, García E, Carnicer P, Pena E, Larrión M, Legarreta JA, et al. Fine and ultrafine emission dynamics from a ferrous foundry cupola furnace. J Air Waste Manage Assoc. 2010;60(5):556-67, https://doi.org/10.3155/10473289.60.5.556.

2. Krieger D, Krieger S, Jansen O, Gass P, Theilman L, Lichtnecker $\mathrm{H}$. Manganese and chronic hepatic encephalopathy. Lancet. 1995;346:270-3, https://doi.org/10.1016/S0140-67 36(95)92164-8.

3. Mergler D, Baldwin M. Early manifestations of manganese neurotoxicity in humans: An update. Environ Res. 1997;73:92-100, https://doi.org/10.1006/enrs.1997.3710.

4. Lucchini R, Bergamaschi E, Smargiassi A, Festa D, Apostoli P. Motor function, olfactory threshold, and hematological indices in manganese-exposed ferroalloy workers. Environ Res. 1997;73:175-80, https://doi.org/10.1006/enrs. 1997.3702.

5. Jankovic J. Searching for a relationship between manganese and welding and Parkinson's disease. Neurology. 2005;64(12):2021-8, https://doi.org/10.1212/01.WNL.0000 166916.40902 .63 .

6. Lander F, Kristiansen J, Lauritsen JM. Manganese exposure in foundry furnacemen and scrap recycling workers. Int Arch Occup Environ Health. 1999;72(8):546-50, https:// doi.org/10.1007/s004200050414.

7. Huang C, Lu C, Chu N, Hochberg F, Lilienfeld D, Olanow W, et al. Progression after chronic manganese intoxication. Neurology. 1993;43(8):1479, https://doi.org/10.12 12/WNL.43.8.1479. 
8. Lucchini R, Albini E, Benedetti L, Borghesi S, Coccaglio R, Malara EC, et al. High prevalence of parkinsonian disorders associated to manganese exposure in the vicinities of ferroalloy industries. Am J Ind Med. 2007;50:788-800, https://doi.org/10.1002/ajim.20494.

9. Baker MG, Simpson CD, Stover B, Sheppard L, Checkoway $\mathrm{H}$, Racette BA, et al. Blood manganese as an exposure biomarker: State of the evidence. J Occup Environ Hyg. 2014;11(4):210-7, https://doi.org/10.1080/15459624. 2013.852280 .

10. Laohaudomchok W, Lin X, Robert F, Fang S, Cavallari JM, Christiani DC, et al. Toenail, blood and urine as biomarkers of manganese exposure. J Occup Environ Med. 2011;53(5):506-10, https://doi.org/10.1097/JOM.0b $013 \mathrm{e} 31821854 \mathrm{da}$.

11. Zhou YZ, Chen J, Shi XJ, Zou Y, Shen XB, Zheng W, et al. Early biological markers of manganese exposure. Chin J Ind Hyg Occup Dis. 2010;28(9):645-7.

12. Chang Y, Jin SU, Kim Y, Shin KM, Lee HJ, Kim SH, et al. Decreased brain volumes in manganese-exposed welders. Neurotoxicology. 2013 Jul;37:182-9, https://doi.org/ 10.1016/jneuro.2013.05.003.

13. Chang Y, Kim Y, Woo ST, Song HJ, Kim SH, Lee H, et al. High signal intensity on magnetic resonance imaging is a better predictor of neurobehavioral performances than blood manganese in asymptomatic welders. Neurotoxicology. 2009;30(4):555-63, https://doi.org/10.1016/j.neuro.2009.04.002.

14. Gebremichaeil D, Mohammed T. Risk factors and public health significance of cysticercosis in cattle and human in Shire Indaselassie district, Northern Ethiopia. Adv Biol Res. 2013;7(6):282-7.

15. Zenz C. Occupational medicine. 3rd ed. St. Louis: Mosby; 1994.

16. Aschner M, Aschner JL. Manganese neurotoxicity: Cellular effects and blood-brain barrier transport. Neurosci Biobehav Rev. 1991;15:333-40, https:/doi.org/10.1016/ S0149-7634(05)80026-0.

17. Mirmohammadi S, Moghaddasi Y, Jalahi H. Indoor air pollution modeling based on flour dust in industrial and traditional bakeries. World Appl Sci J. 2012;17(6): 786-91.

18. Ansari AS, Pandis SN. Water absorption by secondary organic aerosol and its effect an inorganic aerosol behavior. Environ Sci Technol. 2000;34:71-7, https:/doi. org/10.1021/es990717q.

19. Martin-Cameán A, Molina-Villalba I, Jos A, IglesiasLinares A, Solano E, Cameán AM et al. Biomonitorization of chromium, copper, iron, manganese and nickel in scalp hair from orthodontic patients by atomic absorp- tion spectrometry. Environ Toxicol Pharmacol. 2014; 37:759-71, https://doi.org/10.1016/j.etap.2014.01.025.

20. Alessio L, Lucchini R. Manganese and manganese compounds. In: Argentesi F, Roi R, Marcos JMS, editors. Data profiles for selected chemicals and pharmaceuticals. Ispra: European Commission, Joint Research Centre; 1997.

21. Andersen ME, Gearhart JM, Clewell HJ. Pharmacokinetic data needs to support risk assessment for inhaled and ingested manganese. Neurotoxicology. 1999;20:161-72.

22. Mahoney JP, Small WJ. Studies on manganese: III. The biological half-life of radiomanganese in man and factors which affect this half-life. J Clin Invest. 1968;47:643-53, https://doi.org/10.1172/JCI105760.

23. Mirmohammadi M, Hakimi M, Anees A, Omar AK, Mohammadyan M, Mirashrafi SB. Indoor air pollution evaluation with emphasize on HDI and biological assessment of HDA in the polyurethane factories. Environ Monit Assess. 2009;165:341-7, https://doi.org/10.1007/s10661-0090950-5.

24. Zhou YZ, Chen J, Shi XJ, Zou Y, Shen XB, Zheng W, et al. Early biological markers of manganese exposure. Chin J Ind Hyg Occup Dis. 2010;28(9):645-7.

25. Bader M, Dietz MC, Ihrig A, Triebig G. Biomonitoring of manganese in blood, urine and axillary hair following low-dose exposure during the manufacture of dry cell batteries. Int Arch Occup Environ Health. 1999;72(8): 521-7, https://doi.org/10.1007/s004200050410.

26. Myers JE, Thompson ML, Ramushu S, Young T, Jeebhay MF, London L, et al. The nervous system effects of occupational exposure on workers in a South African manganese smelter. Neurotoxicology. 2003;24(6):885-94, https://doi.org/10.1016/S0161-813X(03)00081-0.

27. Evans DE, Heitbrink WA, Slavin TJ, Peters TM. Ultrafine and respirable particles in an automotive grey iron foundry. Ann Occup Hyg. 2008;52(1):9-21, https://doi.org/10. 1093/annhyg/mem056.

28. Bast-Pettersen R, Ellingsen DG, Hetland SM, Thomassen Y. Neuropsychological function in manganese alloy plant workers. Int Arch Occup Environ Health. 2004; 77:277-87, https://doi.org/10.1007/s00420-003-0491-0.

29. Ellingsen, DG. Hetland, SM. Thomassen Y. Manganese air exposure assessment and biological monitoring in the manganese alloy production industry. J Environ Monit. 2003;5:84-90, https://doi.org/10.1039/b209095c.

30. Cowan DM, Fan Q, Zou Y, Shi X, Chen J, Aschner M, et al. Manganese exposure among smelting workers: Blood manganese-iron ratio as a novel tool for manganese exposure assessment. Biomarkers. 2009;14(1):3-16, https://doi. org/10.1080/13547500902730672. 
31. Zheng W, Fu SX, Dydak U, Cowan DM. Biomarkers of manganese intoxication. Neurotoxicology. 2010;32(1):1-8, https://doi.org/10.1016/j.neuro.2010.10.002.

This work is available in Open Access model and licensed under a Creative Commons Attribution-NonCommercial 3.0 Poland License / Ten utwór jest dostępny w modelu open access na licencji Creative Commons Uznanie autorstwa - Użycie niekomercyjne 3.0 Polska - http://creativecommons.org/ licenses/by-nc/3.0/pl/deed.en. 